\title{
Assessment of Healthcare-Associated Infections in the Pediatric Intensive Care Unit
}

\author{
çocuk Yoğun Bakım Ünitesindeki Hastane \\ Enfeksiyonlarının Değerlendirilmesi
}

\author{
Can Celiloğlu' ', Orkun Tolunay ${ }^{1}$, Tamer Çelik' ${ }^{1}$ Asena Sucu' ${ }^{1}$ Eray Yurtçu', Ümit Çelik' \\ 'Department of Pediatrics, Adana Numune Training and Research Hospital, Adana, Turkey
}

\begin{abstract}
Objective: In this study, we aimed to retrospectively investigate the frequency of healthcare-associated infections, infection sites, culture proven microorganisms and antibiotic resistance properties registered in the surveillance system, in our Pediatric Intensive Care Unit over the past five years.

Material and Methods: The data of healthcare-associated infections detected in patients in our 12-bed pediatric intensive care unit, which are all third-level, were collected from January 1, 2012 to December 31,2016 retrospectively. Infection rate and density were made. Culture proven microorganisms and antibiotic resistance properties were recorded.
\end{abstract}

Results: The data of 2545 patients who were followed in the pediatric intensive care unit during the study period were collected. Mortality rate was $9 \%$. The total number of in patient days was 20.696 . The median age of the patients was 3 years (min: 2 months, max: 18 years). The total number of patients with health care-associated infection was 60 , the infection rate was 2.36 and infection density was 2.89 . Laboratory-proven bloodstream infection was detected in 15 patients and the rate of infection was 0.59 and the density was 0.72 . In seven patients, central venous catheter-related bloodstream infection was observed and the rate of infection was 0.27 and the density was 0.33 . In nine patients, catheter-related urinary tract infection was detected and the rate of infection was 0.35 and the density was 0.43 . Ventilatorassociated pneumonia was observed in 30 patients and the rate of infection was 1.18 and the density was 1.44 . Isolated microorganisms were as follows: Pseudomonas aeruginosa in 17 cases, Acinetobacter baumannii in 14 cases, Klebsiella pneumoniae in 9 cases, Serratia
Özet

Giriş: Bu çalışmada Çocuk Yoğun Bakım ünitemizde son beş yılda sürveyans sisteminde kayıtlı hastane enfeksiyonlarının sıklığı, enfeksiyon alanları, kültürlerde üretilen mikroorganizmalar ve antibiyotik direnç özelliklerinin geriye dönük olarak incelenmesi amaçlandı.

Gereç ve Yöntemler: Tamamı üçüncü basamak olan 12 yataklı çocuk yoğun bakım ünitemizde 1 Ocak 2012-31 Aralık 2016 döneminde yatan hastalarda tespit edilen hastane enfeksiyonlarının verileri geriye dönük olarak toplandı. Enfeksiyon hızı ve dansite hesaplamaları yapıldı. Kültürlerde üretilen mikroorganizmalar ve antibiyotik direnç özellikleri kaydedildi.

Bulgular: Çalışma periyodu boyunca çocuk yoğun bakıma yatırılarak tedavi edilmiş olan 2545 hastanın verileri toplandı. Mortalite oranı \%9 idi. Yatan hasta gün sayısı 20.696 idi. Hastaların yaşları ortanca 3 yaş (min: 2 ay, maks: 18 yaş) idi. Toplam hastane enfeksiyonu olan hasta sayısı 60 , enfeksiyon hızı 2.36 ve enfeksiyon dansitesi 2.89 idi. Laboratuvar ile kanıtlanmış kan dolaşımı enfeksiyonu 15 hastada saptandı ve enfeksiyon hızı 0.59 , dansitesi 0.72 olarak hesaplandı. Yedi hastada santral venöz kateter ilişkili kan akımı enfeksiyonu gözlenmişti ve enfeksiyon hızı 0.27 , dansitesi 0.33 bulunmuştu. Dokuz hastada kateter ilişkili üriner sistem enfeksiyonu saptanmıştı ve enfeksiyon hızı 0.35 , dansitesi 0.43 olarak hesaplanmıştı. Otuz hastada ventilatör ilişkili pnömoni gözlenmişti ve enfeksiyon hızı 1.18, dansitesi 1.44 bulunmuştu. Kültürde üretilen mikroorganizmalar; 17 olguda Pseudomonas aeruginosa, 14 olguda Acinetobacter baumannii, 9 olguda Klebsiella pneumoniae, 5 olguda Serratia marcescens, 4 olguda Escherichia coli, 4 olguda Candida albicans, iki ol-
Correspondence Address / Yazışma Adresi

Orkun Tolunay

Adana Numune Eğitim ve Araştırma Hastanesi, Çocuk Sağlığı ve Hastalıkları Kliniği, Adana-Türkiye

E-mail: orkuntolunay@yahoo.co.uk OCopyright 2017 by Pediatric
Infectious Diseases Society -Available online at www.cocukenfeksiyon.org OTelif Hakkı 2017 Çocuk Enfeksiyon Hastalıkları Derneği -Makale metnine www.cocukenfeksiyon.org web sayfasından ulaşılabilir 
marcescens in 5 cases, Escherichia coli in 4 cases, Candida albicans in 4 cases, coagulase negative staphylococcus in 2 cases, Candida parapsilosis in 2 cases, Enterococcus faecalis in 1 case, Proteus mirabilis in 1 case and Stenotrophomonas maltophilia in 1 case.

Conclusion: Intensive care units have the highest rates of antibiotic use in our country and around the world. Antibiotic usage is increasing day by day in pediatric intensive care units. Regional and multicenter studies regarding child intensive care units should be conducted to raise awareness about healthcare-associated infections.

Keywords: Antibiotic, pediatric critical care, health care-associated infections

\section{Introduction}

Healthcare-associated infection means the infections that do not exist or is not in the incubation period in the patient when being admitted to the hospital or to another health care institution but have occurred during the care of the patient (1). Instead of hospital-acquired infections, or in other words, nosocomial infections, the term "healthcare-associated infection" is being used today (2). The healthcare-associated infection is the most serious and unexpected effect seeing during patient care and no institutions, clinic or country has been able to solve this problem completely (1). Healthcare-associated infection is to be a significant cause of morbidity and mortality worldwide and in Turkey. Besides morbidity and mortality, it prolongs the duration of inpatient days, increases antibiotic use, and increases the risk of development of multi-antibiotic resistance of pathogens and healthcare costs.

Healthcare-associated infections are observed at a higher rate in intensive care units compared to other healthcare units. This high rate may be explained by more medical instrument use in intensive care units, longer inpatient times, and more invasive interventions. It has been reported that in developed countries the healthcare-associated infection rates in pediatric intensive care are lower than those for adult patients $(3,4)$. In a multi-center study in Europe, it is reported that the healthcare-associated infection incidence in general pediatric units is $1 \%$ while it is $23.6 \%$ in pediatric intensive care (4). The studies conducted in Turkey, in pediatric intensive care units are limited and the healthcare-associated infection rates vary between $9.1 \%$ and $42.5 \%(5-10)$.

Among healthcare-associated infections, except for the intensive care units, the most frequent ones are the urinary system infections, followed by nosocomial pneumonias (2). In the intensive care units, nosocomial pneumonias and ventilator-associated pneumonias are the most frequent ones (2). Bloodstream infections, central venous catheter-associated bloodstream infections and surgical infections are also problematic in the intensive care units; number of cases increase day by day especially as invasive interventions and the use of central venous catheters increase (2). guda koagülaz-negatif stafilokok, iki olguda Candida parapsilosis, birer olguda da Enterococcus faecalis, Proteus mirabilis ve Stenotrophomonas maltophilia idi.

Sonuç: Yoğun bakımlar ülkemizde ve dünyada antibiyotik kullanım oranları en yüksek olan servislerdir ve çocuk yoğun bakımlarda da antibiyotik kullanımı gün geçtikçe artmaktadır. Çocuk yoğun bakım ünitelerine yönelik bölgesel ve çok merkezli güncel çalışmalar yapılarak hastane enfeksiyonları hakkında farkındalık arttırılmalıdır.

Anahtar Kelimeler: Antibiyotik, çocuk yoğun bakım, hastane enfeksiyonları

The causative agents of healthcare-associated infections in intensive care units and their resistances to antibiotics vary in time and by units. However, there is a general increase in the number of infections caused by multi-resistant gram-negative microorganisms; resistant Enterococcus and Staphylococcus species have started to be serious clinical problems (11). Throughout the world, more than 80 antibiotics have been introduced in the last 80 years, and in the last 30 years, there has been a decrease of $90 \%$ in the number antibiotics approved by the American Food and Drug Administration (FDA) (12). The rate of developing resistance to antibiotics is higher than the rate of developing new antibiotics. Current, the efforts to discover new antibiotics frequently fail due to serious resistance rates (12). It seems as if complete prevention of resistance development to antibiotics is impossible however, we can slow down resistance development $(13,14)$.

In this study, we aimed to retrospectively investigate the frequency of healthcare-associated infections, infection sites, culture proven microorganisms and antibiotic resistance properties registered in the surveillance system, in our Pediatric Intensive Care Unit over the past five years.

\section{Materials and Methods}

In the present study, the data of healthcare-associated infections detected in patients in our high level, 12-bed Pediatric Intensive Care Unit containing bedside echocardiography, plasmapheresis, hemodiafiltration, 10 mechanical ventilators in the Adana Numune Training and Research Hospital, which are all third-level, were collected from January 1, 2012 to December 31, 2016 retrospectively. The healthcare-associated infection diagnosis and definitions have been assessed according to the "Centers for Disease Control and Prevention $(C D C)$ " criteria $(2,15,16)$. The healthcare-associated infection were classified as "surgery site infections", "bloodstream infections", "urinary system infections", "ventilator-associated infections" and "catheter-associated bloodstream infections".

\section{Definitions}

Number of inpatient days is the total number of days of hospitalization $(1,2,17)$. 
Healthcare-associated infection means the infections that do not exist or is not in the incubation period in the patient when being admitted to the hospital or to another health care institution but have occurred during the care of the patient (17).

Ventilator days is used to express the total number of days that a patient gets ventilator support (17).

Ventilator usage rate was calculated according to ventilator days/inpatient days (17).

Infection rate was calculated according to the number of infections/number of inpatients $x 100$ (17).

Infection density was calculated according to the number of infections/inpatient days x1000 (17).

\section{Ethical Approval}

The approval for this study was given by the "Non-Interventional Clinical Research Ethical Board of the Cukurova University".

\section{Statistical Analyses}

Statistical analyses were carried out using the Statistical Package for Social Sciences" version 20 (IBM Corp., Armonk, NY, USA) software. The descriptive statistics of the parametric numerical values in the study group were calculated as average \pm standard deviation and the non-parametric ones are calculated as median (interquartile range-IQR) and the categorical data are given as percentage (\%).

\section{Findings}

The number of patients hospitalized in the Pediatric Intensive Care Unit between 01.01.2012 and 31.12.2016 was 2545 . Of these, 2220 (87.3\%) were Turkish citizens and 323 (12.7\%) were individuals temporarily under protection in Turkey. In the data for the last one year (2016) the proportion of the individuals temporarily under protection in Turkey was $25.8 \%$. The average age of the patients was 3 (min: 2 months, maximum: 18 years old, IQR: 11). The number of inpatient days was 20.696. Ventilator days were 12.587 and ventilator usage rate was 0.60 . The total number of patients with healthcare-associated infection was 60 , infection rate was 2.36 and infection density was calculated as 2.89 .

Surgical site infection developed only in one patient, who was being monitored in the Pediatric Intensive Care Unit after tracheostomy. Since the surgical site infection developed only in one patient, based on the data for the year it occurred (2016), the infection rate was 0.27 and the density was 0.22 . bloodstream infection, as proven by laboratory, developed in 15 patients; the infection rate was 0.59 and the infection density was 0.72 . Apart from the patients with bloodstream infection, as proven by laboratory, catheter-associated bloodstream infection was observed in seven cases; the infection rate was 0.27 and the infection density was 0.33 . In nine cases, urinary system infection was detected; the infection rate was 0.35 and the infection density was 0.43 . Ventilator-associated pneumonia was observed in 30 patients; the infection rate was 1.18 and the infection density was 1.44 .

In healthcare-associated microorganisms grown in culture we as follows: Pseudomonas aeruginosa in 17 (28\%) cases, Acinetobacter baumannii in 14 (\%23) cases, Klebsiella pneumoniae in $9(15 \%)$ cases, Serratia marcescens in $5(8 \%)$ cases, Escherichia coli in $4(7 \%)$ cases, Candida albicans in 4 (7\%) cases, coagulase-negative staphylococcus (CNS) in two cases, Candida parapsilosis in two cases, Enterococcus faecalis in one case, Proteus mirabilis in one case and Stenotrophomonas maltophil$i a$ in one case (Figure 1). The bloodstream infection agents, as proven by laboratory, were $K$. pneumoniae in 4 cases, S. marcescens in 3 cases, A. baumannii in 3 cases, $C$. parapsilosis in two cases, and one case in each of $C$. albicans, P. aeruginosa and CNS. The agents for catheter-associated bloodstream infection were A. baumannii in 4 cases, $P$. aeruginosa in one case, $C N S$ in one case and $E$. coli in one case. In ventilator-associated pneumonia agents, the most frequent one was $P$. aeruginosa (50\%, 15/30), followed by A. baumannii $(40 \%, 12 / 30)$ (Figure 2). The agents that caused urinary system infections were $C$. albicans in two cases, P. aeruginosa in one case, K. pneumonia in one case, E. coli in one case, and S. marcescens in one case.

In healthcare-associated infections, in general, $93 \%$ of the A. baumannii strains is resistant to carbapenem, but there was no colistin resistance. $55.6 \%$ of the $K$. pneumoniae strains is resistant to carbapenem; this proportion was $65 \%$ in P. aeruginosa and $56 \%$ in K. pneumoniae (Table 1). Resistance to colistin was not detected among microorganisms grown in culture in healthcare-associated infections.

In the Pediatric Intensive Care Unit a total of 230 patients were died within five years, the mortality rate being $9 \%$.

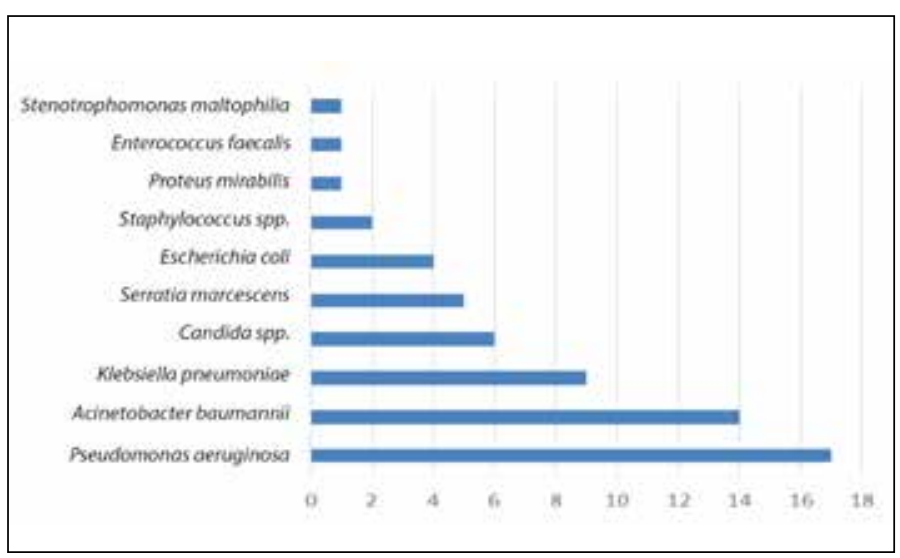

Figure 1. Microorganisms grown in cultures. 


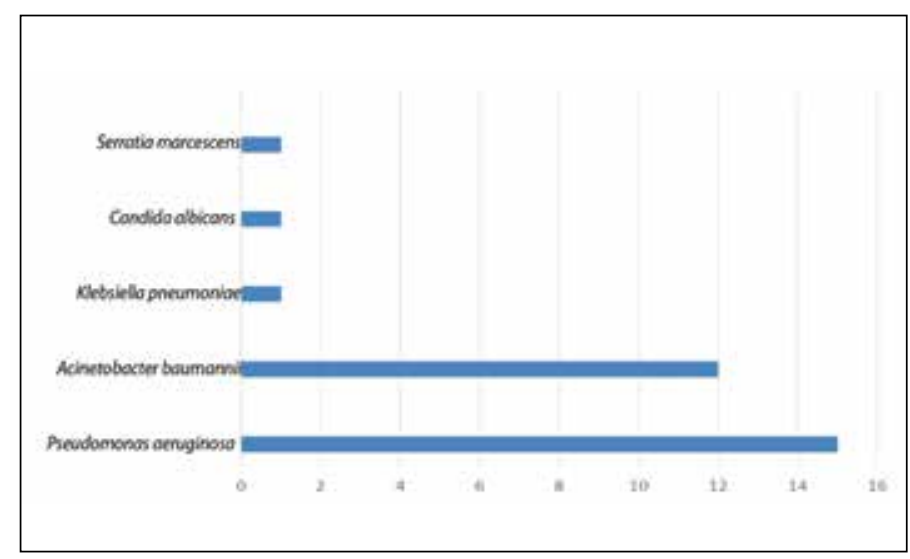

Figure 2. Ventilator-associated pneumonia agents.

\section{Discussion}

Despite early diagnosis of infections, improvement in hospital conditions and the advances in supporting treatments, healthcare-associated infections are continuing to cause an important mortality and morbidity risk. Healthcare-associated infections also increase care costs.

The microbiological agents responsible for healthcare-associated infections vary from one region to another, even from one unit to another (18). The resistance properties of microbiological agents also vary in time (14). In developed countries, there are numerous studies concerning healthcare-associated infections in pediatric intensive care units, however, such studies in Turkey are relatively limited. In previous years, Staphylococcus aureus was the most frequent; however, today, the most frequently encountered agents of healthcare-associated infections in both children and in adult patients are Pseudomonas, Klebsiella and Acinetobacter species as well as the CNS strains $(10,19,20)$. In the present study, gram-negative agents appeared to be more frequent than the Staphylococcus strains and were compatible with the literature (Figure 1).

Bloodstream infections are one of the main subtypes of healthcare-associated infections both worldwide and in Turkey $(7,16)$. In a multi-centered point prevalence study conducted in Turkey, in 322 cases, laboratory proven bloodstream infection was detected in 24 (7.3\%) (21).
In a Europe-centered, multinational study, among 710 cases hospitalized in intensive care units within 6 months, it was reported that bloodstream infection was not associated with central catheter in 13 (1.9\%) patients and was associated with central catheter in 21 (2.9\%). In the same study (including all pediatric cases), the most frequent bloodstream infection agents were detected to be CNS, Klebsiella spp., S. aureus, $P$. aeruginosa (4). In our cases the bloodstream infection agents were as follows: K. pneumoniae in 4 cases, $S$. marcescens in 3 cases, A. baumannii in 3 cases, C. parapsilosis in two cases, and in one case for each of $C$. albicans, P. aeruginosa and CNS. Although in some studies, Candida spp. are reported to be the main agent for healthcare-associated infection in children, no Candida spp. Growth was observed in the bloodstream infections in our clinic (22).

Currently, infection rates have increased as the use of central venous catheters increased, however, with the precautions taken in time, infection rates have decreased. Examining the the course of catheter-associated bloodstream infection in time in various pediatric intensive care units, it is observed that the rate of catheter-associated bloodstream infections was on the average $5.8 \pm 2.94 \%$ (4.5-7.11) in 2006; however, it has decreased to $1.4 \pm 1.16 \%$ (1.16-1.64) in 2011-2012 (23). In our unit, the catheter-associated bloodstream infection was at a low rate, namely $0.27 \%$. It was believed that this low rate could be the result of conducting the operation of placing the central catheter under absolute supervision of the expert physician, complying with the guidelines published concerning catheter-associated bloodstream infection, placing the central catheters in our unit under ultrasonography and having short central catheter times $(24,25)$.

The urinary tract infection associated with catheter/cannula is one of the most frequent causes of healthcare-associated infections (26). In a study conducted in a pediatric intensive care unit in Turkey, it was reported that the most frequent healthcare-associated infection was the urinary tract infection (3). The studies conducted show that the most frequent infection agent associated with unrinary catheterization is $E$. coli, followed by Klebsiella spp., Enterococcus spp., P. mirabilis, P. aeruginosa, Candida spp. as main agents (26). In the present

Table 1. Resistance pattern of microorganisms

\begin{tabular}{|c|c|c|c|c|c|c|}
\hline & Colistin & Amikacin & Meropenem & Cefepime & Ceftazidime & $\begin{array}{l}\text { Piperacillin/ } \\
\text { Tazobactam }\end{array}$ \\
\hline $\begin{array}{l}\text { Acinetobacter } \\
\text { baumannii }\end{array}$ & $\begin{array}{c}\text { Sensitive 100\% } \\
\text { Resistant 0\% }\end{array}$ & $\begin{array}{l}\text { Sensitive } 43 \% \\
\text { Resistant 57\% }\end{array}$ & $\begin{array}{c}\text { Sensitive 7\% } \\
\text { Resistant 93\% }\end{array}$ & $\begin{array}{c}\text { Sensitive 7\% } \\
\text { Resistant 93\% }\end{array}$ & $\begin{array}{c}\text { Sensitive 7\% } \\
\text { Resistant 93\% }\end{array}$ & $\begin{array}{c}\text { Sensitive 7\% } \\
\text { Resistant 93\% }\end{array}$ \\
\hline $\begin{array}{l}\text { Pseudomonas } \\
\text { aeruginosa }\end{array}$ & $\begin{array}{c}\text { Sensitive 100\% } \\
\text { Resistant 0\% }\end{array}$ & $\begin{array}{l}\text { Sensitive } 35 \% \\
\text { Resistant } 65 \%\end{array}$ & $\begin{array}{l}\text { Sensitive } 35 \% \\
\text { Resistant } 65 \%\end{array}$ & $\begin{array}{l}\text { Sensitive } 35 \% \\
\text { Resistant } 65 \%\end{array}$ & $\begin{array}{l}\text { Sensitive 30\% } \\
\text { Resistant 70\% }\end{array}$ & $\begin{array}{l}\text { Sensitive } 24 \% \\
\text { Resistant } 76 \%\end{array}$ \\
\hline $\begin{array}{l}\text { Kleibsella } \\
\text { pneumoniae }\end{array}$ & $\begin{array}{c}\text { Sensitive } 100 \% \\
\text { Resistant 0\% }\end{array}$ & $\begin{array}{l}\text { Sensitive } 33 \% \\
\text { Resistant 67\% }\end{array}$ & $\begin{array}{l}\text { Sensitive 44\% } \\
\text { Resistant 56\% }\end{array}$ & $\begin{array}{l}\text { Sensitive } 11 \% \\
\text { Resistant } 89 \%\end{array}$ & $\begin{array}{c}\text { Sensitive 0\% } \\
\text { Resistant 100\% }\end{array}$ & $\begin{array}{l}\text { Sensitive } 22 \% \\
\text { Resistant } 78 \%\end{array}$ \\
\hline
\end{tabular}


study, there was C. albicans in 2 cases and one case for each of E. coli, K. pneumoniae, S. marcescens and P. aeruginosa growth, which is similar to literature data. In a prevalence study conducted in European countries, urinary system infection was detected in $1.3 \%$ of the patients; our data was lower than the data of this study $(0.81 \%)$ (27). In the present study, it was believed that the low level rates detected in urinary tract infections was the result of the practice that urine cannula placing times are kept short, taking them of as soon as the urinary catheterization requirement finishes. In studies conducted in pediatric intensive care units, ventilator-associated pneumonia rate varied between $5-13.1 \%$, whereas in our study the number of patients with ventilator-associated pneumonia was 30 (1.18\%) (21).

Starting with the 90s, the increase in infections caused by multi-resistant gram-negative microorganisms has been a serious clinical problem worldwide (11). Multi-resistant gram-negative bacteria are serious mortality and morbidity causes in Turkey too and similarly, in the present study, multi-resistant gram-negative bacteria stand out (Table 1). The Acinetobacter species, which are widespread and important healthcare-associated agents worldwide, are detected at a high rate, namely $23 \%$ in the present study too. The point that catches the eye in the present study is that these Acinetobacter species are carbapenem resistant at a high rate, namely $93 \%$. The species $P$. aeruginosa, which is the most frequent agent (28\%), had 65\% carbapenem resistance while another important agent, K. pneumonia, 56\% carbapenem resistance. In the present study, no resistance to colistine, which had been disfavored due to its nephrotoxic side effects for some period but had been used again in recent years against carbapenem resistant microorganisms such as $P$. aeruginosa, $A$. baumannii and $K$. pneumoniae, was detected (28).

The main restriction of the present study was that it was retrospective. Other restrictions were inadequate contents of files, the incomplete data in surveillance recordings, which were detected during the study, and not being able to compare crude mortality rates with healthcare-associated mortality rates. In the present study, in general, the healthcare-associated rates are observed to be low. Especially, the ventilator-associated pneumonia rates are lower than the expected. Even though general infection and ventilator-associated pneumonia preventing measures in our pediatric intensive care unit are being implemented, the number of cases are still lower and this low rate is considered to originate from incomplete file contents and recordings, which is the most important restriction of the present study.

\section{Conclusion}

The number of pediatric intensive care units are increasing day by day although can not catch up the ideal number. Pediatric intensive care units are different from adult intensive care units in many respects. Intensive care units are the units where antibiotic use is the highest worldwide and in Turkey and the use of antibiotics is increasing day by day in pediatric intensive care units too. Awareness on healthcare-associated infections must be raised by regional and multi-center up-to-date studies concerning pediatric intensive care units. Especially, preparation of local and national treatment guides concerning multi-resistant gram-negative microorganisms, which narrow our treatment options, must be brought on the agenda. Considering that new generations of antibiotics are not expected to be used in the coming years, fighting with infections, especially with healthcare-associated infections, is very important.

Ethics Committe Approval: Ethics committee approval was received for this study from the ethics committee of "T.C. Çukurova Üniversitesi Girişimsel Olmayan Klinik Araştırmalar Etik Kurulu". (05/05/2017-Toplantı sayısı: 64, Karar no: 3).

Informed Consent: Written informed consent was not obtained due to the retrospective nature of this study.

Peer-review: Externally peer-reviewed.

Author Contributions: Concept - ÜÇ, OT, CC, TÇ; Design - CC, ÜÇ, OT, AS; Supervision - ÜÇ, OT, TÇ; Materials - OT, CC, AS, EY; Data Collection and/or Processing - CC, AS, OT, EY; Analysis and/or Interpretation - OT, ÜÇ, TÇ, AS, EY; Literature Review - CC, OT, ÜÇ, AS, EY; Writing - CC, OT; Critical Review - ÜÇ, OT, TÇ

Conflict of Interest: No conflict of interest was declared by the authors.

Financial Disclosure: The authors declared that this study has received no financial support.

\section{References}

1. The burden of health care-associated infection worldwide, World Health Organization Web site. Avaible at: http://www.who.int/gpsc/ country_work/burden_hcai/en. Accessed July 16, 2017.

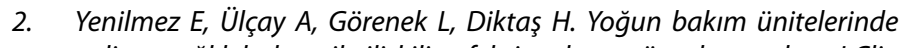
gelişen sağlık bakımı ile ilişkili enfeksiyonların güncel tanımları. J Clin Anal Med 2015;6:401-4.

3. Kuzdan C, Soysal A, Culha G, Altinkanat G, Soyletir G, Bakir M. Threeyear study of health care-associated infections in a Turkish pediatric ward. J Infect Dev Ctries 2014:8:1415-20.

4. Raymond J, Aujard Y. Nosocomiat infections in pediatric patients: a European, multicenter prospective study. European Study Group. Infect Control Hosp Epidemiol 2000;21:260-3. 
5. Grohskopf LA, Sinkowitz-Cochran RL, Garrett DO, et al. A national pointprevalence survey of pediatric intensive care unit-acquired infections in the United States. J Pediatr 2002;140:432-8.

6. Richards MJ, Edwards JR, Culver DH, Gaynes RP. Nosocomial infections in pediatric intensive care units in the United States. Pediatrics 1999;103:e39.

7. Lee $\mathrm{WK}$, Chlu CS, Chow $\mathrm{VC}$, Lam RK, Lal RW. Prevalence of hosplat infection and antibiotic use at a university medical center in Hong Kong. J Hosp Infect 2007;65:341-7.

8. Durando P, Icardi G, Ansaldi F, et al. Survellance of hospital acquired infections in Liguria, Italy: results from a regional prevalence study in adult and paediatric acute-care hospitals. J Hosp Infect 2009;71:81-7.

9. GravelD, Matlow A, Ofner-AgostinI M, et al. A point prevalence survey of health care-associated infections in pediatric populations in major Canadian acute care hospitals. Am J Infect Control 2007;35:157-62.

10. AtICI S, Soysal A, Kepenekiा Kadayifç E, et al. Healthcare-associated infections in a newly opened pediatric intensive care unit in Turkey: Results of four-year surveillance. J Infect Dev Ctries 2016;10:254-9.

11. Hsu AJ, Tamma PD. Treatment of multidrug-resistant Gram-negative infections in children. Clin Infect Dis 2014;58:1439-48.

12. Spellberg B. The future of antibiotics. Crit Care 2014;18:228.

13. Tolunay 0 , ÇelikU, YücelG, et al. Antibiotic use in pediatric and neonatal intensive care units; multicenter point prevalence study. J Pediatr Inf 2014;8:56-63.

14. Gould IM. Antibiotic resistance: the perfect storm. Int J Antimicrob Agents 2009;34(Supple 3):S2-5.

15. Horan TC, Andrus M, Dudeck MA. CDC/NHSN surveillance definition of health care-associated infection and criteria for specific types of infections in the acute care setting. Am J Infect Control 2008;36:309-32.

16. Refik Saydam Hıfzıssıhha Merkezi Başkanlığı Ulusal Hastane Enfeksiyonları Sürveyans ve Kontrol Birimi. Tarafından Belirlenen Hastane Enfeksiyonu Tanımları. TC Sağlık Bakanlığı; Ankara: 2009.

17. Parlak E, Kahveci $H$, Alay HK. Nosocomial infections in neonatal intensive care unit. J Curr Pediatr 2014;1:1-8.
18. Hacımustafaoğlu M, Çelebi S, Tuncer E, Özkaya G, Çakır D, Bozdemir ŞE. Çocuk kliniği ve çocuk yoğun bakım ünitesi hastane enfeksiyonları sıklığ. J Pediatr Inf 2009;3:112-7.

19. Aktar F, Tekin $R$, Güneş $A$, et al. Determining the independent risk factors and mortality rate of nosocomial infections in pediatric patients. Biomed Res Int 2016;2016:7240864.

20. Pérerz Lopéz A, Ladhani SN, Breathnach A, Planche T, Heath PT, Sharland $M$. Trends in paediatric nosocomial bacteraemia in a London tertiary hospital. Acta Paediatr 2013;102:1005-9.

21. Kepenekाt E, soysal A, Yalindag-Ozturk $N$, el al. Heathcare-assoclated infections in pediatric intensive care units in Turkey: a national pointprevalence survey. Jpn J Infect Dis 2015;68:381-6.

22. Becerra MR, Iantaleán JA, Suarez VJ, Alvarado MC, Candela JL, Urcla FC. Epidemiologic surveillance of nosocomial infections in a Pediatric Intensive Care Unit of a developing country. BMC Pediatr 2010;10:66.

23. EdwardsJD, Herzig CI, LIuH, et al. Centralline-associated blood stream infections in pediatric intensive care units: Longitudinal trends and compliance with bundle strategies. Am J Infect Control 2015;43:489-93.

24. Tolunay O, Okuyan MK, Çelik T, Mert MK, Çelik U, Gülek B. Use of ultrasound for central venous catheterization in pediatric intensive care unit; a single center experience. J Pediatr Emerg Intensive Care Med 2015;2:127-32.

25. O'Grady NP, Alexander $M$, Burns $L A$, et al. Summary recommeddations: Guidelines for the prevention of intravascular catheter-related infections. Clin Infect Dis 2011;52:1087-99.

20. Nicolte LE. Catheter associated uninary tract infections. Antimicrob Resist Infect Control 2014;3:23.

77. Larb P, Coignard B, Griskevicienne J, et al. The European Centre for Disease Prevention and Control (ECDC) pilot point prevalence survey of healthcare-associated infections and antimicrobial use. Euro Surveill 2012:17:20316.

28. Oncül O. Kolistin: Endikasyon ve klinik kullanımı. ANKEM Derg 2012;26:12-8. 